\section{Renesansowe modernizacje kroniki uniwersalnej}

Dariusz Śnieżko
NARODOWY PROGRAM ROZWOJU HUMANISTYKI tu NPRH $11 \mathrm{H}_{13} 030282$.

TEKSTY DRUGIE 2019, NR 2, S. 22-31

DOI: 10.18318/td.2019.2.3 | ORCID: 0000-0003-0247-9900

$\mathbf{S}$ kodyfikowana postać średniowiecznej kroniki uniwersalnej wywodzi się z właściwej dla późnej starożytności tendencji do pogodzenia antycznych porządków chronologicznych z chrześcijańską wizją czasu linearnego, podzielnego na segmenty (jak ery, wieki czy monarchie) i zmierzającego do eschatologicznego finału. W ujęciu chrześcijańskim historia powinna być uniwersalna, prowidencjalna, apokaliptyczna i podległa periodyzacji'. Przedsięwzięcie takie wymagało zatem uzgodnienia rozbieżnych chronologii stosowanych przez różne ludy, a także - w szerszym sensie - rozładowania napięcia między historia sacra i historia profana.

Rozwojowa energia tej atrakcyjnej średniowiecznej formy pochodziła z doświadczenia różnicy $\mathrm{i}$ - jak byśmy dziś powiedzieli - niekompatybilności różniących się pochodzeniem układów chronologicznych: od zasadniczej różnicy w rozumieniu czasu (czas cykliczny versus

\section{Dariusz Śnieżko}

- dr hab., profesor nadzwyczajny w Zakładzie Teorii i Antropologii Literatury Instytutu Polonistyki, Kulturoznawstwa i Dziennikarstwa Uniwersytetu Szczecińskiego. Ostatnio opublikowana książka: „Kronika wszytkiego świata" Marcina Bielskiego. Pogranicze dyskursów (2004).Zajmuje się przede wszystkim badaniami kulturowymi nad literaturą dawną i poetyką historyczną.

1 R.G. Collingwood The Idea of History, Clarendon Press, Oxford 1962, S. 46-52. 
czas linearny), po odmienne sposoby jego porządkowania. Z drugiej strony - przezwyciężenie różnic nie powodowało usunięcia ich z pamięci gatunku, przeciwnie: zadanie przezwyciężenia nieusuwalnych różnic można uznać za coś w rodzaju jego kodu źródłowego, fundującego genologiczną tożsamość. Wymuszona współobecność rywalizujących porządków: świętego i świeckiego, pogańskiego i judeochrześcijańskiego, wywarła trwały wpływ na kompozycję, postawę wobec źródeł i autorytetów, a wreszcie na samą ideę uniwersalności, nieuchronnie naznaczonej paradoksem niekoherentnej koherencji, chociaż sama zasada syntezy - u jej początków - była raczej prosta. Raz, chodziło o pogodzenie rozbieżnych tradycji segmentowania osi czasu (olimpiady i konsulaty versus lata rachowane od zrekonstruowanego stworzenia świata czy Wcielenia Chrystusa²); dwa - w aspekcie materiałowym - o kompilację, czyli zaaranżowaną współpracę konsultowanych autorów i przekazów: chrześcijańskich przed pogańskimi lub żydowskimi, wcześniejszych przed późniejszymi, historykami przed poetami, swoimi (np. polskimi) przed obcymi (np. węgierskimi), świadectwem pisemnym przed świadectwem ustnym.

Pierwotna forma synchronizacji kalendarza również była prostą formą tablicy paschalnej, ustalającej dni świąt w cyklu roku liturgicznego. Z kolei podstawowym ujęciem współbieżności historii świętej i świeckiej były paralelne listy papieży i cesarzy. Kronika Euzebiusza z Cezarei (ok. 275-339), zwłaszcza w łacińskiej przeróbce św. Hieronima (ok. 347-420) uważana jest za początkowy punkt dziejów gatunku, który stopniowo podzielił się na trzy warianty, przez Doroteę von den Brincken nazwane Series temporum, Mare historiarum i Imago mundi. Series temporum to - przypomnijmy ${ }^{3}$ - niewyszukany projekt mający na celu chronologiczną koordynację następstwa zdarzeń datowanych a to od początku świata i według monarchii, a to według olimpiad, a to od założenia miasta i kolejnych konsulatów. Mare historiarum to wersja wzbogacona o moralne przykłady, dygresje i pozostałe informacje, z konieczności rozluźniające nieco gorset chronologiczny. Wreszcie Imago mundi to encyklopedyczna odmiana o najbogatszej faktografii i najswobodniejszej kompozycji. Rzec można, że samo to zestawienie odzwierciedla narastanie komponenty narracyjno-opisowej, w wydaniach luksusowych uzupełnianej o atrakcyjną oprawę ilustracyjną. Z zastrzeżeniem że mowa raczej o ujęciu typologicznym;

2 Zob. B. Kürbis Nad apokryfem historii, w: tejże Na progach historii ll. O świadectwach do dziejów kultury Polski średniowiecznej, Wydawnictwo Poznańskie, Poznań 2001, s. 300.

3 Typologię omawia K.H. Krüger Die universalchroniken, Brepols, Turnhout 1976, s. 21-23. 
późna historia gatunku rejestruje bowiem współobecność wszystkich trzech wariantów: przykładem opublikowana w 1592 roku Chronologia seu temporum series Jakuba Gislo, m.in. w posiadaniu biblioteki Ossolińskich"

Powszechna opinia za najpiękniejsze wcielenie Imago mundi uznała $\mathrm{Li}$ ber chronicarum Hartmanna Schedla (Norymberga 1493, w oficynie Antona Kobergera), głównie dzięki ilustracjom drzeworytniczym Michaela Wolgemuta i Wilhelma Pleydenwurffa, z których niektóre osiągnęły poziom arcydzieła. Robota Schedla zdaje sprawę ze wszystkiego, co najistotniejsze dla poprzedzającej go i zaakceptowanej przezeń tradycji: periodyzacja polega na Augustyńskiej sekwencji sześciu wieków świata, uzupełnionej o spodziewany wiek siódmy, który będzie zamknięty Dniem Sądu. Chociaż bibliofilski księgozbiór Schedla liczył więcej niż tysiąc tomów (bardzo dużo w tamtych czasach), informacje czerpał on głównie z Supplementum chronicarum Jacopo Philippo Foresti da Bergamo (1483) - dzieła ufnie kontynuującego wzorce średniowieczne, popularnego, ale nie lekceważonego przez humanistów: Marcantonio Sabellico, o którym za chwilę, w prywatnym liście do autora zabiegał o wymienienie go wśród najsłynniejszych uczonych ${ }^{5}$. Rozkładając materiał historyczny, Schedel nie trzymał się rygorystycznego wzorca znanego np. z Kroniki cesarzy i papieży Marcina z Opawy ${ }^{\mathbf{6}}$, gdzie strony recto pokazują sukcesję cesarską, a strony verso - papieską. Liber chronicarum kontynuuje ideę linii chronologicznej wyłącznie w postaci wertykalnie ułożonej serii drzeworytniczych portretów, sama natomiast narracja nie przestrzega żadnego powtarzalnego porządku, przynosząc wiadomości o świętych, biskupach, pisarzach, a nawet sławnych lekarzach, wyodrębniając osobne paragrafy dla anegdot, obszernych opisów geograficznych, charakterystyk herezji itd. Dane chronologiczne znajdują się na początku paragrafów; dla pięciu wieków (stworzenie świata - Potop - Abraham - Dawid - niewola babilońska - narodziny Chrystusa) lata policzono od stworzenia świata, a szósty datowany jest Anno Domini. Zachłanna erudycja Schedla nie wpłynęła na jego - zasadniczo - średniowieczną praktykę pisarstwa historycznego,

4 J. Gislo Chronologia seu temporum series ab initio mundi ad nostra haec tempora praesentia..., Gutterwitz, Stokholmiae 1592.

5 W.J. Connell Italian Renaissance Historical Narrative, w: The Oxford History of Historical Writing, ed. by D. Woolf, vol. 3: 1400-1800, ed. by J. Rabasa, M. Sato, E. Tortarolo, D. Woolf, Oxford University Press, Oxford 2012, s. 356.

6 M. Polak Kronika papieży i cesarzy, przekł. pol. i kom. A. Fabiańska, J. Soszyński, wstęp J. Soszyński, Wydawnictwo Marek Derewiecki, Kęty 2008. 
ciągle wystarczająco elastyczną, żeby zorganizować potężny korpus wiedzy - dawnej i nowej.W samej rzeczy, był to wówczas jedyny dostępny model do zaprojektowania uniwersalnej panoramy historycznej, a Schedel nie wystąpił z własną inicjatywą modyfikacji, ponieważ nie widział innego wyboru.

Po pięciu jednakże latach sytuacja została zmieniona przez Marcantonia Coccia zwanego Sabellico, który podjął się przeformułowania gatunku odpowiednio do nowych humanistycznych oczekiwań. Jego największe dzieło zatytułowane Enneades sive Rhapsodia historiarum (w dwóch częściach: 1498, 1504) rozpoczyna się formułą ab orbe condito - w oczywistym nawiązaniu do Liwiańskiego wzorca retorycznego. Przyznać zarazem trzeba, że kronika ta podziela z innymi imagines mundi brak krytycznego zaplecza i niezdolność do selekcji ogromnego materiału; obszerne partie narracji są kompilacją lub zostały po prostu przepisane $\mathrm{z}$ historiografii antycznej. Z interesującego nas tu punktu widzenia najważniejszą innowację stanowi systematyczna periodyzacja dziejów według jedenastu ennead („dziewiątek”) - odpowiednio każdą z nich podzielono jeszcze na dziewięć ksiąg. Grecki termin enneas odnosi się tyleż do dziewięciu bogów egipskich, ile do Plotyna, i wskazuje dobitnie na antyczny patronat całości, z wymownym pominięciem kościelnej tradycji podziału na wieki, monarchie, a także paraleli historii świętej i świeckiej. Przykładowo: pierwsza enneada w dziewięciu księgach obejmuje materiał od stworzenia świata do króla Salomona, druga od Salomona do tragedii Koriolana, trzecia od Koriolana do wyroczni zapowiadającej inwazję Gallów. Oznacza to, że periodyzacja nie ogranicza się tu do zaprowadzenia pewnego formalnego, numerycznego porządku według ennead, ksiąg, lat - zewnętrznego, czyli niewyprowadzonego z rozeznanej fabuły procesu historycznego w rozumieniu średniowiecznym. Punkty węzłowe periodyzacji nie odnoszą już przebiegu wypadków dziejowych do spodziewanego schematu historii świętej - w tej roli występują bowiem także zdarzenia z porządku historii świeckiej, uprawnione przez ideę kumulacji i repetycji, z epoką antyku w roli prototypu. Także rapsodia - jako tytułowa etykieta gatunku, odsyła do wzorcowej starożytności, co wyłożył sam autor w przedmowie, ubranej w formę listu do Demokryta.

W odróżnieniu od Schedla, który miał na oku kształconego w łacinie, ale popularnego czytelnika, Enneady Sabellika wypatrywały odbiorcy z wyższych, akademickich lub szkolnych kręgów. Masywne tomy były tłoczone bez ilustracji; monotonny układ, abstrakty przed każdą enneadą, ogólne wrażenie systematycznej, ale i bezkresnej lektury - wszystko to (jak można sobie wyobrażać) ograniczało publiczność do zaprawionych, wytrwałych 
i kompetentnych czytelników, wyposażonych w to, co Niemcy nazywają Sitzfleisch. Wśród gatunków dziejopisarstwa humanistycznego nie było dotąd kroniki powszechnej - wydaje się otóż, że celem Sabellica było wypełnienie pustego miejsca w repertuarze modnych, stylowych gatunków przez zmodernizowanie starej formy. Zapewne, w rewizji założeń kompozycyjno-periodyzacyjnych gatunku projekt ten szedł najdalej spośród omówionych tu przykładów, ale konceptualnie był raczej prosty. Przedsięwzięcie powiodło się, jeśli sądzić po licznych przedrukach; niemniej - co może znaczące - model opracowany przez autora nie znalazł naśladowców.

To samo należy powiedzieć o innym pomyśle na modernizację, zrealizowanym przez Johannesa Nauclerusa (właśc. Verge lub Vergenhans, zm. 1510), pierwszego rektora uniwersytetu w Tybindze. Jego kronika zatytułowana Memorabilium omnis aetatis et omnium gentium chronici commentarii (editio posthuma 1516) powstała dzięki inspiracji cesarza Maksymiliana I. Pierwsze wydanie zostało opatrzone przedmową Erazma z Rotterdamu, który inicjatywę pochwalił, starając się zarazem usprawiedliwić niedostatki elegancji stylistycznej ${ }^{7}$. Ogólnie mówiąc, metodologiczne stanowisko autora było raczej konserwatywne i nie zamierzał on kontestować tradycji średniowiecznej. Księga obejmuje zdarzenia ab exordio mundi do roku 1500. Zasadę kategoryzacji przeszłości zapowiedział Nauclerus w przedmowie: i tak, całość podzielono na dwa tomy, odpowiednio do dwóch er: carnalis i spiritualis, a tę ostatnią otworzyło Wcielenie Chrystusa. Następstwo sześciu wieków i czterech monarchii zostało utrzymane, podlega ono jednak dodatkowemu podziałowi na 130 generacji, czyli formalnych modułów chronologicznych, obejmujących po parę dekad. Każdej generacji odpowiada rozdział rozpoczynający się od daty rocznej, dla pierwszej ery ustalonej od Stworzenia, dla drugiej - anno salutis nostrae.

Takie rozwiązanie wydaje się kompromisem między tradycyjną dziejopisarską analogią mikro- i makrokosmosu a nowoczesną tendencją do wdrożenia bardziej precyzyjnego, ideowo neutralnego schematu. Do pewnego stopnia przypomina ono innowacje Sabellica, z takim samym wrażeniem nudnej szkolnej pedanterii. Nauclerusa ceni się dzisiaj za erudycję z pierwszej ręki, ale i tak obszerne fragmenty jego opowieści są po prostu przepisane z obowiązkowych źródeł, jak np. Historia scholastica Piotra Komestora (co na swój sposób wyjaśnia dostrzeżone przez Erazma niedomogi stylu). Pożyteczna

7 P.G. Bietenholz, T.B. Deutscher Contemporaries of Erasmus: A Biographical Register of the Renaissance and Reformation, vol. 2, University of Toronto Press, Toronto 2003, s. 7. 
dla studentów jako systematyczne i - dzięki powierzchownej modernizacji - łatwe do przeszukiwania kompendium, kronika ta była kilkakrotnie przedrukowywana do XVII wieku.

Następnym przykładem historii powszechnej w zmienionych kształtach jest Chronica Johannesa Cariona: lekarza, astrologa i luterańskiego dziejopisa. Dzieło to, po raz pierwszy ogłoszone w 1532 roku jako kieszonkowy podręcznik, szybko przełożone na łacinę przez Hermana Bonnusa i głęboko przepracowane przez Filipa Melanchtona, było w ciągu dwóch stuleci wznawiane, tłumaczone na francuski $(1553,1595)$ i angielski $(1550)$. Ta wersja gatunku miała odpowiadać specyficznym protestanckim potrzebom. Jako całość kronika zachowawczo kontynuuje (a zarazem odświeża) millenarystyczną interpretację historii. Podstawowym układem periodyzacyjnym jest adaptowany przez protestantów podział na cztery monarchie, uzupełniony przez wywiedzione z apokryficznego Proroctwa Eliasza następstwo trzech dwutysiącletnich okresów: Inane, Lex i Dies Messiae ${ }^{\mathbf{8}}$, a także średniowieczną ideę translatio imperii, naznaczoną przez umiarkowaną, ale wyraźną tendencję ideologiczną: ostatnia, czwarta monarchia powinna być kojarzona z zepsuciem papieskiego Rzymu i ostatnią fazą upadku świata. Waloryzację historii autor oparł na scenariuszu degeneracyjnym i apokaliptycznym, nadając wczesnemu chrześcijaństwu status prototypu. Całość dzieli się na trzy księgi, a zawartość została uporządkowana według kryteriów osobowych (królów, cesarzy itd.). Jak należało się spodziewać, linia papieska nie odgrywa tutaj żadnej istotnej roli. W stosunku do kronik średniowiecznych to oczywiście znacząca zmiana, ale - ogólnie mówiąc - wdrożona przez Cariona reinterpretacja gatunku nie wpłynęła na tradycyjną aranżację chronologii. Profil protestancki jest czytelny przede wszystkim na podstawie wyborów dokonywanych w zakresie zastanych możliwości, sposobu rozłożenia akcentów i nacisku na aktualne znaczenie doktryny o czterech monarchiach.

Jednym z uważnych czytelników przypomnianych tu autorów był Marcin Bielski. Miałem już okazję wypowiedzieć się obszerniej na temat jego kroniki $(1551,1554,1564)^{9}$, zatem poruszę tylko sprawy najważniejsze dla tytułowego zagadnienia. Bielski pilnie studiował m.in. Sabellica, Nauclerusa, Schedla

8 O znaczeniu kroniki Cariona - Melanchtona i Proroctwa Eliasza dla luterańskiego millenaryzmu zob. M. Woszczek Eliasz nauk. Apokaliptyka, paracelsjańska mistyka przyrody i narodziny nowoczesności (Część pierwsza), „Praktyka Teoretyczna” 2016 nr 1 (19). 
i Cariona, ale rezultat tej rozległej kwerendy wskazuje, że polski historyk nie chciał korzystać z modernizacyjnych pomysłów swoich poprzedników, choć od każdego coś wziął. Szukał jednak własnej drogi, a punktem dojścia jest trzecie, najobszerniejsze wydanie z 1564 roku $^{10}$. Najbardziej śmiałą decyzją było ograniczenie konwencjonalnej kroniki świata do dwóch ksiąg - całość liczy dziesięć. Reszta to zasadniczo samodzielne części poświęcone kosmografii, Turkom, rozwojowi ruchu protestanckiego (któremu Bielski otwarcie sprzyjał), dziejom Węgier, Czech, Polski, Rusi, a wreszcie odkryciom geograficznym. Od Schedla autor i wydawcy wzięli pomysł uzupełnienia tekstu atrakcyjnymi ilustracjami. Carionowi kronika zawdzięcza interpretację idei czterech monarchii, profetyczną perspektywę, niektóre informacje i tablice chronologiczne. Nauclerus był głównym informatorem dla dwóch pierwszych ksiąg, ale pedantyczna sekwencja generacji została słusznie zlekceważona, a to samo można powiedzieć o enneadach Sabellica.

Zamiast szkolarskiego rygoru Bielski zaproponował czytelnikom pozornie niespójny, ale znacznie szerszy, panoramiczny, gatunkowo urozmaicony przegląd tego, co w jego czasach wydawało mu się najważniejsze i najciekawsze. Niewątpliwy sukces Bielski zawdzięczał trafnemu rozpoznaniu wolnego miejsca na polskim renesansowym rynku wydawniczym, a także ustaleniu odpowiedniego adresu czytelniczego. Kompilacja ta była bowiem efektem wysiłku adaptacyjnego, włożonego w popularyzację podstawowego korpusu wiedzy, po raz pierwszy udostępnionego w języku polskim, uwzględniała też poznawcze i propagandowe interesy rodzimych środowisk protestanckich. Ostatnie wydanie sprawiać może wrażenie, że część poświęcona historii powszechnej, znacznie mniej szczegółowa od wersji Nauclerusa czy Jakuba da Bergamo, miała uzasadnić obecność reszty: znacznie obszerniejszej, ważniejszej i bardziej atrakcyjnej.

Zdyscyplinowane umysły Nauclerusa i Sabellica unowocześniały gatunek, uzupełniając lub zastępując średniowieczny model periodyzacji własnymi autorskimi nakładkami: generacjami i nneadami. Carion z Melanchtonem usiłowali dostosować przestarzały paradygmat do bieżących potrzeb, odpowiednio nim manipulując (rezygnacja z paraleli cesarsko-papieskiej, aktualizacja podziału na cztery monarchie). Bielski jeszcze inaczej: głęboko

10 M. Bielski Kronika, to jest historyja świata na sześć wieków a czterzy monarchije rozdzielona z rozmaitych historyków tak w Świętym Pismie krześcijańskim, żydowskim, jako i pogańskim wybierana i na polski język wypisana dostateczniej niż pierwej, z przydanim wiele rzeczy nowych. Od początku świata aż do tego roku, który sie pisze 1564, z figurami ochędożnymi i własnymi, Mateusz Siebeneicher, Kraków 1564. Zostawiamy "sie" zgodnie z oryginałem 
zreorganizował gatunek w aspekcie kompozycyjnym. Całość otwiera opis Stworzenia, a zamyka zapowiedź Dnia Sądu, ale składowe księgi, podobnie jak niektóre rozdziały, mogą być czytane niezależnie. Porządek uległ panoramicznej, żywiołowej rozmaitości. Widać to wyraźnie m.in. w księdze poświęconej historii rodzimej: Bielski, czerpiąc, głównie za Maciejem z Miechowa, z Długosza, rozbija porządek chronologiczny, scalając wątki rozbite między lata - tym samym niektóre daty roczne mogą tylko orientacyjnie wskazywać na odpowiednie miejsce na osi dziejów.

Można by więc sądzić, że nie rywalizując z humanistami, autor znalazł dla niemodnej formy niszę przetrwania w obiegu popularnym. Wydawcy Ennead Sabellicusa dedykowali pośmiertne wydanie z 1560 roku Zygmuntowi Augustowi.Ten sam adres dedykacyjny otwiera łacińską przedmowę do Kroniki albo historyi świata z 1564 roku Marcina Bielskiego, który pokusił się o propozycję konkurencyjną: polskojęzyczną, samodzielną opowieść o świecie, do czytania i słuchania w domu. Kroniki powszechne w średniowiecznym formacie drukowano u nas jeszcze w XVIII wieku, zdegradowane do postaci szkolnych, raczej prymitywnych podręczników. Samemu Bielskiemu natomiast zaszkodził profil wyznaniowy jego przyszłej publiczności. Katoliccy czytelnicy z XVII, XVIII wieku zostawiali na marginesach egzemplarzy adnotacje żywo przypominające dzisiejszy internetowy hejt. Nie można już było tego tekstu wznawiać ani - w tej postaci - kontynuować, stanowił jednak dla wielu vademecum niezastąpione, bo jedyne. Czytali więc, zgrzytając zębami na papieżycę Joannę"1, Marcina Lutra i z pasją atakując ich portrety.

Podsumujmy: żadna z przypomnianych tu wersji nie zreorganizowała głębiej wzorca, ponieważ było na to za wcześnie - zważywszy na procesualny charakter zmian, wyznaczanych przez Wielkie Odkrycia geograficzne i naukowe. Niewątpliwie kronika uniwersalna to gatunek o łatwo uchwytnych cechach i o stabilnej pozycji w repertuarze form historiograficznych. Zarazem gatunek ten był szczególnie mocno uzależniony od długiego trwania średniowiecznej epistemy, która powołała go do życia i którą wiernie reprezentował. Zakładała ona, jak wiadomo, dostępne poznawczo uniwersum o uchwytnych (czasowo i przestrzennie) granicach, niewykraczających poza analogię mikro- i makrokosmosu. Tego rodzaju pogląd na świat, już - w tym co najważniejsze - opisany przez autorytety, uzasadniał (wraz z okolicznościami komunikacyjnymi, czyli ekskluzywnością pisma) swobodną eksploatację

11 Por. Historia o kobiecie papieżu, oprac. J. Sokolski, Oficyna Wydawnicza ATUT - Wrocławskie Wydawnictwo Oświatowe, Wrocław 2013. 
dorobku poprzedników. Przedstawionym wyżej wysiłkom zmierzającym do zreformowania gatunku na progu wczesnej nowożytności po staremu patronowała idea „tekstu generalnego” (czyli starej nauki). W jego obrębie spełniała się dynamika przetasowań materiału: tłumaczeń, parafraz, kopii, wersji - zgodnie z nadrzędnym rozumieniem piśmiennictwa jako repetycji. Dopóki bowiem trwała (choćby w zmiennym już, niepewnym zakresie) epistemiczna matryca gatunku, zamknięta była droga do otwartej intelektualnej konfrontacji na płaszczyźnie odziedziczonych konwencji. Sabellico budzi dzisiaj zainteresowanie (i kontrowersje) nie jako autor kroniki powszechnej, tylko jako oficjalny - i badawczo jednak bardziej samodzielny - dziejopis Wenecji $^{\mathbf{1 2}}$, którego dzieło Rerum venetarum ab urbe condita libri XXXIII (1487) uzyskało pierwszy znany przywilej wydawniczy ${ }^{\mathbf{1 3}}$.

Miarą żywotności kroniki uniwersalnej (i poznawczej wydolności stojącej za nią epistemy) była zdolność do przyswajania coraz to nowych porcji wiedzy. Gatunek ten, jako tako wytrzymujący konfrontację z retorycznymi ambicjami humanistów, zaczął poważnie trzeszczeć w szwach na widok Ameryki, a pożegnały go (wraz ze skrupulatną chronologią biblijną) narodziny nowożytnej geologii ${ }^{14}$.

12 Zob. Ș.V. Marin Marcantonio Sabellico's Rerum Venetarum and "the Definitive History of Venice". The Beginnings of the Official Historiography in Venice?, "Revista Arhivelor" 2013 No. 1/2. thistory.org/cam/tools/request/showRecord?id=commentary_i_1486 (4.04.2018). 


\section{Abstract}

\section{Dariusz Śnieżko}

UNIVERSITY OF SZCZECIN

Renaissance Modernisations of the Universal Chronicle

The article concerns selected Renaissance initiatives to modernise the medieval universal chronicle in terms of genre. Marcus Antonius Coccius Sabellicus (Enneades sive Rhapsodia historiarum $[. .], 1498,1504$.$) proposed a humanistic version that did away with temporal$ divisions according to the world's ages and the four monarchies in favour of a secular chronological system of enneads (sets of nine). Johannes Nauclerus, a more conservative scholar (Memorabilium omnis aetatis [...],1516), came up with a compromise solution: he maintained the periodical canon but added an "overlay" in the form of 130 Generations. Johannes Carion (Chronica, 1533) adapted the medieval model to the needs of Protestantism by reinterpreting the concept of the four monarchies. Finally, Marcin Bielski (Kronika wszytkiego świata, 1551) proposed a radical reconfiguration, an encyclopaedic collection of relatively independent parts with a selective and autonomous relationship to its predecessors.

\section{Keywords}

Renaissance, genre, universal chronicle, periodisation, composition 